\title{
PENDEKATAN PROSES PENGIDENTIFIKASIAN PENGETAHUAN PERUSAHAAN UNTUK MEMAKSIMALKAN AKSELERASI SEBAGAI LANDASAN KNOWLEDGE MANAGEMENT SYSTEM
}

\author{
Win Ce \\ Information Systems Department, School of Information Systems, Binus University \\ Jl. K.H. Syahdan No. 9, Palmerah, Jakarta Barat 11480 \\ wn@binus.edu
}

\begin{abstract}
The high increment of competition currently requires companies to have more values to offer to customers. Company must also truly understand what the core of the companies is as the reason of customers continuing the cooperation with the company. In its growth of knowledge management it clearly provide direction and a real acceleration to the company. The biggest problem is the lack of the ability of companies to see and identify the main knowledge and the main core in the company. This study discusses the best approach to identify the existing knowledge in the company as the basis for the development of the companies and for the construction of knowledge management system.
\end{abstract}

Keywords: core of company, main knowledge, knowledge management system

\begin{abstract}
ABSTRAK
Perkembangan persaingan saat ini menuntut perusahaan memiliki nilai lebih yang bisa ditawarkan ke pelanggannya. Di samping itu, perusahaan juga harus betul-betul memahami apa yang menjadi core atau inti dari perusahaan yang selama ini menjadi alasan para pelanggan tetap menjalin kerjasama dengan perusahaan tersebut. Dalam perkembangannya, knowledge management memberikan arahan dan akselerasi nyata untuk perusahaan. Permasalahan terbesar adalah kurangnya kemampuan perusahaan untuk melihat dan mengidentifikasikan apa pengetahuan utama dan apa core utama yang ada di perusahaan tersebut. Studi ini membahas pendekatan terbaik untuk mengidentifikasi pengetahuan yang ada di perusahaan sebagai dasar pengembangan perusahaan maupun untuk pembangunan knowledge management system.
\end{abstract}

Kata kunci: inti perusahaan, pengetahuan utama, knowledge management system 


\section{PENDAHULUAN}

Fokus pengembangan sistem informasi saat ini tidak lagi hanya berfokus pada SIM atau $e$ application saja. Kebutuhan akselerasi organisasi dan keharusan organisasi untuk mulai focus ke asset intelektual, menjadi dorongan baru ke arah knowledge management. Pentingnya peran knowledge management sudah sangat dirasakan ditengah persaingan termasuk tingkat turn over karyawan yang semakin tinggi.

Dengan adanya knowledge management akan membuat perusahaan bisa dengan jelas menjaga knowledge yang ada di organisasinya. Tidak sebatas itu saja, diharapkan juga bisa memberikan gambaran dan focus yang jelas tentang asset intelektual yang penting dan utama bagi organisasi.

Kendala terbesar yang dihadapi dalam pembangunan knowledge management adalah dititik awal ketika perusahaan berusaha memahami dan mengerti apa yang menjadi core knowledge di organisasinya. Proses identifikasi knowledge yang salah akan membawa arah pembangunan knowledge management system yang juga salah dan focus organisasi juga akan keliru.

Dalam paparan ini diharapkan akan bisa memahami kendala yang biasanya muncul dalam mengidentifikasikan knowledge yang kemudian bisa dilanjutkan dengan usaha untuk memahami dengan jelas caranya membangun suatu transparansi knowledge di organisasi. Dari knowledge yang sudah diidentifikasi bisa dilakukan analisis dan kemudian dilakukan pemetaan termasuk pemahaman tentang pembangunan sistem untuk pemetaan di dalam organisasi.

\section{METODE}

Dalam memberikan pemaparan tentang metode terbaik untuk mengidentifikasikan knowledge yang ada diperusahaan didasarkan pada hasil dari beberapa pendekatan yang dilakukan yaitu: (1) mempelajari dari beberapa literatur tentang paparan pendekatan terbaik untuk melakukan identifikasi terhadap knowledge yang ada di perusahaan; (2) melakukan evaluasi sebagai hasil identifikasi knowledge dalam beberapa implementasi pembangunan knowledge management yang diterapkan untuk perusahaan. Metodologi yang diimplementasikan dalam proses mengidentifikasikan knowledge yang dipaparkan di sini sebagai sebuah acuan yang dapat digunakan oleh perusahaan dalam melakukan proses ini di perusahaan nantinya.

\section{HASIL DAN PEMBAHASAN}

\section{Apa Itu Identifikasi Knowledge?}

Banyak sekali istilah dalam knowledge management (KM) untuk menggambarkan proses dari identifikasi knowledge ini. Secara sederhana sebenarnya proses ini adalah mencoba melihat apa saja knowledge yang sudah dimiliki oleh perusahaan. Jadi perusahaan akan mencoba menginventarisasi knowledge yang sudah dimiliki oleh perusahaan tersebut. Identifikasi seringkali dianggap sekedar faktor internal. Jadi kita melihat di internal kita apa yang sudah dimiliki.

Tahapan ini menjadi salah satu yang penting dalam proses KM, karena ini sebagai titik awal melihat apa yang kita punya. Ini merupakan dasar melihat apa saja yang nantinya akan dikelola di 
dalam perusahaan dalam artian knowledge. Kesalahan identifikasi di sini akan menyebabkan aspek yang dikelola di sistem KM nantinya akan salah arah.

Identifikasi perlu dilakukan secara lengkap karena ini akan digunakan dalam menentukan bentuk dan tatacara mengelola nantinya. Secara garis besar faktor yang harus di dalami ketika mengetahui adanya suatu knowledge yaitu dengan melihat beberapa komponen. Pertama, 'siapa yang akan menggunakan knowledge tersebut?' Ini menjadi kunci untuk melihat suatu knowledge. Knowledge penting karena digunakan oleh orang-orang dalam organisasi dalam membantu bekerja apalagi yang secara strategis. Kedua, ‘untuk apa knowledge tersebut digunakan?’ Ini akan membantu melihat tingkat strategis dari knowledge yang akan dikelola nantinya, khususnya ketika harus menentukan prioritas dalam pembangunan. Ini juga akan digunakan dalam penentuan sudut pandang dalam penampilan informasi yang memang sesuai dengan penggunaannya masing-masing. Ketiga, 'apa isi dari knowledge tersebut?' Secara khusus kita harus melihat juga apa saja isi dari knowledge tersebut dan dalam penggunaannya apa saja yang digunakan. Nantinya ini akan berguna ketika kita akan menstrukturkan datanya agar mudah dikelola dan disimpan. Jadi, isi dari knowledge harus disusun secara rinci pada proses ini, sekaligus untuk menganalisis komponen yang berguna atau tidak dari isi tersebut.

\section{Permasalahan dalam Identifikasi Knowledge}

Banyak faktor yang menjadi kesulitan dalam melakukan identifikasi terhadap knowledge. Pertama adalah ketidaksadaran dari internal perusahaan tentang aset pengetahuan. Karyawan di perusahaan seringkali mengerjakan suatu pekerjaan sebagai bagian dari kebiasaan; merasa apa yang dilakukan merupakan hal yang umum dan merasa semua orang juga bisa mengerjakan hal tersebut. Faktor ini bisa disebabkan karena sudah lamanya karyawan tersebut bekerja dan seringnya berkecimpung dalam menyelesaikan faktor tersebut. Sangat sering seorang karyawan ketika ditanyakan knowledge yang dibutuhkan untuk mengerjakan pekerjaannya, lebih banyak memaparkan aspek yang terlalu umum dan tidak spesifik kepekerjaannya diorganisasi tersebut. Faktor ini bisa juga dipicu karena perasaan yang merasa apa yang dikerjakan tersebut tidak ada sesuatu yang spesial dan hanya hal umum saja. Hal lain adalah adanya sesuatu yang sebenarnya dimiliki oleh perusahaan baik data atau keahlian tertentu dari karyawannya yang tidak disadari. Banyak keahlian yang peran dan manfaatnya tidak secara langsung disadari berperan dalam mempercepat kemajuan di organisasi. Ini juga bisa berupa data atau informasi penting yang tingkat kepentingannya belum ditelusuri atau belum disadari oleh karyawan.

Kedua adalah informasi yang terlalu banyak. Perusahaan yang sudah memiliki SIM yang baik bisanya mempunyai data yang lengkap tentang banyak aspek. Begitu juga informasi yang berasal dari luar perusahan seperti masukan dari pelanggan, pemasok ataupun berita dan informasi yang umum beredar. Karena banyaknya data yang mengalir, ada kecenderungan untuk tidak meneliti dan mendalami setiap data yang ada untuk dimanfaatkan. Sehingga sering terjadi informasi yang penting yang bisa membawa perusahaan tenggelam ke level yang lebih jauh di antara banyaknya data yang mungkin sebagian besar tidak berguna karena tidak tertata. Banyak jawaban dan solusi dari permasalahan perusahaan sudah ada dalam perusahaan itu sendiri hanya saja belum tereksplorasi misalnya dalam laporan-laporan di cabang-cabang lain, riset di cabang lainnya atau dokumentasi proyek yang memberi solusi yang sudah pernah implementasi tetapi tidak bisa tereksplorasi.

Ketiga adalah konsep memadai, tidak mutlak dan transparan. Dalam melakukan identifikasi terhadap knowledge, tiga konsep ini bisa mewakili prinsip dasar pemikiran dalam melakukannya. Memadai dalam artian knowledge yang diidentifikasikan harus dalam cakupan yang lengkap dan tidak sekedar lalu saja. Ini harus bisa masuk sampai ke core dari bisnis utama. Jadi, cakupan harus cukup memadai. Tidak ada acuan atau dasar khusus tentang knowledge apa yang harus dimasukkan atau tidak boleh dimasukkan. Ini mendasari konsep tidak mutlak di sini. Maksudnya segala aspek yang 
memungkinkan sebagai knowledge perlu untuk dimasukkan sebagai bagian dari identifikasi tanpa perlu melakukan pembatasan-pembatasan khusus. Nanti baru akan ditentukan prioritas dalam menentukan yang mana yang akan dikelola. Selalu semua karyawan harus bergerak untuk melakukan tranparansi, sehingga semua akan dengan terbuka menguraikan knowledge yang dimiliki untuk membantu analisis pembangunan KM.

Keempat adalah visibilitas karyawan dan struktur. Umumnya perusahaan dalam melakukan penyusunan terhadap struktur organisasi dan juga dalam menentukan posisi tiap karyawan lebih mengutamakan faktor pekerjaan yang sifatnya operasional. Penekanan perlu untuk memastikan apa yang sudah ada berjalan dahulu. Jadi apa yang kelihatan dari hasil pekerjaan karyawan dan struktur yang diperlukan itu yang diutamakan. Orang-orang di organisasi yang justru mengembangkan struktur pengembangan knowledge justru sangat sering dinomorduakan. Ketika kondisi krisis seperti saat ini dan perusahaan dituntut untuk melakukan penghematan, bisa dipastikan faktor yang pertama kali dipangkas adalah faktor pengembangan karyawan atau area-area yang tidak terlihat manfaatnya secara langsung ke operasional perusahaan. Faktor KM adalah yang paling sering dikorbankan pertama kali di organisasi.

\section{Mengidentifikasikan Knowledge External}

Seperti paparan sebelumnya, knowledge sangat sering diidentifikasikan dengan faktor internal. Faktor eksternal juga mempunyai kepentingan dalam identifikasi ini dalam beberapa aspek.

Faktor pertama yaitu pemahaman tentang lingkungan knowledge. Melihat faktor lingkungan yang membentuk knowledge dalam perusahaan sangat diperlukan. Contoh sederhana adalah untuk keahlian yang umum diajarkan di pasaran misalnya kursus atau universitas. Perusahaan tidak akan terlalu fokus karena knowledgenya sudah berkembang dan dalam proses pencarian karyawan juga akan lebih mudah. Untuk setiap bidang keahlian lingkungan sekitar yang terpengaruh ke identifikasi knowledge antara lain: (1) pengetahuan inti yang menjadi dasar utama kekuatan perusahaan dibandingkan pesaing lainnya sehingga dengan jelas melihat antara karyawan berpotensi yang perlu dijaga dengan baik; (2) tingkat kemudahan mencari pengganti dari karyawan dengan knowledge tertentu; (3) lamanya waktu adaptasi dan proses belajar untuk knowledge di bidang tertentu; (4) banyak atau sedikitnya data tentang knowledge tersebut di pasaran sehingga bisa mempertimbangkan antara mengambil saja dari yang ada di luar atau membangun sendiri knowledge tersebut di internal perusahaan atau keputusan antara mengirimkan karyawan untuk pelatihan di luar atau mengembangkan sendiri modul training-nya. Faktor kedua yaitu benchmarking atau studi banding. Hal paling mudah dalam pengembangan sistem KM adalah dengan melakukan benckmarking atau studi banding dengan organisasi lain yang serupa yang sudah lebih dahulu atau lebih baik dalam menerapkan sistem KM. Faktor lain yang juga penting yaitu bisa membandingkan tingkat keunggulan dasar atau knowledge inti yang ada dan menjadi kekuatan dari para pemain lain atau para pesaing yang ada di industri. Di sini kita bisa melihat faktor-faktor knowledge yang perlu dikembangkan lagi di organisasi kita untuk lebih meningkatkan kompetensi dan kualitas organisasi.

Ketiga yaitu manfaat dari transparansi knowledge. Saat ini di industri maupun internet tersedia sangat banyak ilmu dan pengetahuan bahkan acuan-acuan yang sangat baik. Organisasi harus belajar melihat apa saja yang sudah ada di lingkungan sekitar sehingga tidak lagi menghabiskan terlalu banyak efford untuk mengembangkan knowledge tertentu yang ternyata sudah tersedia dengan baik dan bisa diakses juga seperti dari buku atau internet. Keempat yaitu implikasi dari mengakui ketidaktahuan. Maksud di sini adalah rasa menerima atau terbuka terhadap aspek dari luar dan bisa dengan jujur menerima atau melihat faktor-faktor yang memang masih belum diketahui oleh perusahaan. Dengan melihat knowledge sekitar, kita bisa lebih mudah melihat faktor yang masih kurang pada kita. 


\section{Transparansi Knowledge}

Kondisi yang paling ideal diharapkan oleh banyak orang adalah terciptanya transparansi dari knowledge. Semua berharap bisa mendapatkan semua knowledge yang diharapkan atau yang diinginkan setiap saat diperlukan. Kondisi yang lebih realistik seharusnya bisa dibangun di dalam perusahaan dengan asumsi, semua yang bekerja di perusahaan mengarahkan atau mempunyai visi yang sama dan sejalan. Di dalam perusahaan diharapkan semua orang bisa mendapatkan semua pengetahuan atau semua knowledge yang dimiliki terkait dengan kebutuhan dan kemajuan organisasi setiap saat. Dengan pendekatan yang sama diharapkan semua orang bisa memberikan dan mengeluarkan knowledge yang dimiliki terkait dengan kebutuhan untuk penyelesaian pekerjaan menjadi knowledge yang explisit. Dengan kondisi ini diharapkan bisa menjadi titik awal untuk melakukan identifikasi knowledge.

Dalam kenyataannya ada beberapa hal yang sering menghalangi terciptanya transparansi knowledge. Pertama karena tidak ada yang secara khusus bertanggung jawab untuk terciptanya tranparansi knowledge. Dalam organisasi seringnya semua orang tidak merasa bertanggung jawab untuk menciptakan transparansi knowledge. Pemikiran dasarnya adalah jika yang lain belum memulai untuk menciptakan transparansi, posisi saya dan daya tawar dari sisi knowledge menjadi lebih lemah. Maka dari itu, secara khusus perlu dicari dan dibentuk tim khusus sebagai knowledge worker menjadi perintis dan pembuka jalan, yang bertanggung jawab untuk memulai transparansi ini. Terkadang banyak orang yang bisa melihat dan mengetahui para ahli di bidang tertentu mengalir atau ada di perusahaan, tetapi lebih sering tidak menyebar ke semua organisasi sehingga adanya pekerja knowledge secara khusus juga bisa mengatasi hal ini. Berikutnya adalah munculnya hal-hal yang mengahalangi orang-orang untuk mengeluarkan apa yang dia punya. Secara khusus dalam kultur Indonesia dimana tingkat kesetiaan terhadap organisasi atau perusahaan tempatnya bekerja sangat rendah. Bisa saja karyawan yang kemarin berperan saat ini bisa disuatu tempat dan bahkan bisa jadi besok sudah bergabung dengan pesaing terdekat kita. Rasa tanggung jawab profesi untuk menjaga knowledge dimana kita pernah berada sangat rendah. Kondisi ini juga menghalangi organisasi untuk secara transparan membuka knowledgenya, karena ada kekhawatiran karyawan yang terlibat akan dengan lebih mudah untuk memindahkan lebih banyak knowledge ke organisasi lainnya khususnya pesaing. Terkadang prinsip saling membajak juga jadi kebiasaan karena terlihat sebagai alternatif yang lebih mudah dan murah dengan mengambil karyawan yang sudah mengerti dibandingkan membina yang baru.

Beberapa pengaruh secara positif yang bisa terlihat dari terciptanya transparansi knowledge yaitu: (1) komunikasi vertikal melalui jalur resmi semakin tergantikan oleh kontak horizontal. Dalam struktur klasik organisasi biasanya komunikasi lebih banyak bersifat vertikal khususnya dalam integrasi antar unit. Semua harus melalui jalur pimpinan unit untuk bertanya ke salah satu staf unitnya. Dengan terciptanya transparansi khususnya dengan knowledge map (lihat penjelasan berikutnya) akan lebih mendorong ke arah hubungan horizontal yang lebih bisa menjangkau lintas karyawan. Dengan komunikasi ini akan lebih meningkatkan konsolidasi, kedekatan dan hubungan baik karyawan; (2) mendayagunakan sumber daya yang ada. Penggunaan dan pemanfaatan infrastruktur akan lebih meningkat. Terbukanya aspek-aspek organisasi yang kuat akan mendorong lebih banyak orang untuk menggunakannya. Di sisi lain area yang kurang efisien dan efektif akan berusaha untuk meningkatkan peranannya agar juga bisa memberikan kontribusi yang seimbang. Aspek ini sebenarnya dari sisi orang juga akan serupa, karena expert yang memiliki keahlian khusus akan lebih terbuka sehingga akan mendorong penggunaan yang lebih luas dan peran yang lebih luas dalam organisasi.

\section{Level Knowledge Organisasi}

Banyak pendekatan yang bisa dilakukan dalam melakukan identifikasi knowledge. Secara umum akan dilakukan inventarisasi terhadap semua knowledge yang ada. Tetapi untuk memudahkan 
sudut pandang atau tata cara inventarisir biasanya dilakukan analisis dengan pendekatan tertentu atau dari lapisan dan tingkat pekerjaan tertentu. Pendekatan bisa dilakukan dengan berdasarkan jenis knowledge dari yang tacit dan explisit. Probst memperkenalkan pendekatan yang lebih mudah untuk melakukan identifikasi knowledge khusus di dalam organisasi/perusahaan. Di sini dia membagi menjadi tiga kelompok knowledge yaitu struktural, aktifitas dan habitual. Pendekatan analisis tetap bisa dikombinasikan dengan knowledge tacit dan expisit untuk melihat seluruh isi knowledge di tiap level/kelompok.

\section{Knowledge Struktural}

Knowledge struktural adalah knowledge yang memang dibentuk atau lahir dari struktural organisasi, jadi di sini merupakan knowledge yang biasanya hadir dalam bentuk tatanan, aturan dan standar. knowledge dianalisis di organisasi berdasarkan aspek struktural untuk melihat apa saja yang dibutuhkan dalam dari setiap struktur pekerjaan hal knowledge. Beberapa contoh yang paling umum ada di tingkat struktural antara lain: (1) struktur organisasi yang dibentuk, dengan rincian tugas dan wewenang. Bisa juga dilengkapi dengan tata cara mengerjakan setiap pekerjaan atau panduan baik secara pengerjaan maupun jangka waktu; (2) prosedur kerja yang ada di perusahaan juga masuk dalam kelompok ini. Di sini prosedur atau tata cara dalam mengerjakan secara jelas diidentifikasi, dilengkapi juga dengan instruksi kerja, termasuk form atau standar isian dan panduan cara membuat atau melakukan pekerjaan; (3) standar kerja juga bisa menjadi bagian dari aspek ini di mana kita misalnya ada standar pengaturan keamanan jaringan atau aspek sejenis yang memang secara lahirnya secara struktural.

\section{Knowledge Aktifitas/Fungsi (Activities/functional)}

Setelah melihat aspek yang memang secara tatanan dasar distruktur, berikutnya melihat secara aktifitas. Knowledge ini sering disebut juga function knowledge karena yang digambarkan di sini lebih menggambarkan fungsi orangnya; lebih detail ke aktifitas dalam mengerjakan setiap pekerjaan atau dalam menjalankan fungsinya. Kita bisa contohkan dalam konteks dosen. Dosen punya knowledge secara struktural seperti aturan perkuliahan seperti proses pengambilan buku dosen dan absensi, keharusan melakukan pengisian absensi dan buku dosen, aturan dan tata cara dosen atau sejenisnya. Sedangkan untuk activities di sini lebih ke dalam perannya misalnya pendekatan cara mengajar, bidang keahlian dalam mengajar, pendekatan cara mengajar yang baik.

\section{Knowledge Perilaku (Behavioral)}

Knowledge ketiga adalah dari sisi budaya. Organisasi biasanya memiliki budaya baik yang secara tidak disadari membangun dan membentuk pola kerja di dalam organisasi tersebut. Hal ini bisa berbentuk hal yang sederhana seperti lomba inovasi dan perbaikan operasi, prinsip kerja 5R (resik, rapi, ringkas, rawat, rajin) atau sesuatu yang serupa dengan itu. Bentuk lain yang lebih umum yaitu adanya pertemuan rutin untuk membahas produk baru atau sharing rutin antara karyawan dan pimpinan. Dalam setiap kegiatan tersebut tercermin content dan knowledge yang akan berguna dalam pengembangan organisasi baik secara karakter, budaya atau masukkan-masukkan itu sendiri. Pemetaan antara jenis dari knowledge (level) ini akan dikombinasikan dengan knowledge goal untuk menghasilkan fitur yang diperlukan dalam pembangunan KM nantinya (penjelasannya dalam knowledge development, ada di pertemuan berikutnya).

\section{Instrumen dan Pengukuran untuk Mencapai Visibilitas Knowledge Internal}

Sangat sering ditemui di organisasi adanya karyawan-karyawan yang setelah mulai bekerja baru diketahui adanya skill atau keahlian yang kurang. Proses ini bisa jadi sebagai bagian dari proses adaptasi awal karyawan tersebut bergabung atau adanya perubahan dan penambahan sistem baru yang 
tidak dengan cepat dikuasai oleh karyawan tersebut. Faktor tak terduga atau terjadinya hal-hal yang insidental juga terkadang perlu keahlian khusus untuk menanganinya.

Salah satu cara untuk mengatasi ini adalah dengan memetakan keahlian semua karyawan atau dengan membantuk mereka dalam team. Di sini diharapkan adanya jalur komunikasi untuk mendapatkan jawaban atas permasalahan atau solusi untuk hal-hal yang dihadapi yang belum diketahui. Proses pembinaan juga bisa menggunakan konsep ini. Di sisi lain juga kita bisa melihat tingkat kualitas dari karyawan yang kita miliki. Solusi yang dikembangkan di sini biasa disebut sebagai knowledge map, walaupun sebenarnya ini merupakan bagian besar yang serupa. Beberapa istilah yang digunakan antara lain: directory of experts, employee yellow pages, knowledge maps, knowledge topographies, maps of knowledge assets, knowledge source maps, dan knowledge matrices. Perbedaan istilah sebenarnya hanya untuk menggambarkan perbedaan cara pembangunan atau perbedaan tujuan dari pengaturan team dan pemetaan keahlian saja. Tetapi secara umum memang lebih sering menggunakan istilah knowledge map.

\section{Knowledge Topographies}

Pada Gambar 1 di bawah ini, organisasi memetakan bidang-bidang keahlian yang diperlukan atau penting. Penyusunan ini diharapkan bisa sedetail mungkin (yang ditunjukkan di gambar masih cukup umum, hanya sebagai contoh gambaran saja). Kemudian baru dipetakan setiap orang di organisasi untuk kemampuan di bidang-bidang tersebut.

Jika sistem sudah dibangun, untuk setiap permasalahan yang dihadapi akan dengan mudah melihat dan mengetahui siapa saja yang bisa membantu mengatasi dan bisa melihat level setiap orang. Evaluasi untuk karyawan dengan kompetensi yang baik juga bisa berdasarkan komponen ini.

\begin{tabular}{|l|l|l|l|l|l|}
\hline Employees & $\begin{array}{c}\text { Introducing } \\
\text { IT }\end{array}$ & $\begin{array}{c}\text { Technology } \\
\text { transfer }\end{array}$ & Finance & Accounting & Marketing \\
\hline McBride. Tim & & & & & \\
\hline Johnson, Sue & & & & & \\
\hline Roberts, Jane & & & & & \\
\hline Jamal, Manny & & & & & \\
\hline Cooper, Mike & & & & & \\
\hline Barton, Jill & & & & & \\
\hline Lewis, Glyn & & & & & \\
\hline
\end{tabular}

Gambar 1. Contoh knowledge topographies.

\section{Knowledge Source Maps}

Knowledge source map di bawah ini (Gambar 2) lebih menonjolkan tim kerja yang disusun untuk setiap orang. Terlihat yang menjadi ahli atau expert-nya dan team yang dibentuknya. Di luar team terdapat juga anggota yang sifatnya lebih teratur yang bisa menjadi sumber untuk team tersebut. Secara cakupan yang lebih luas expert bisa menjadi sumber dari faktor external. 


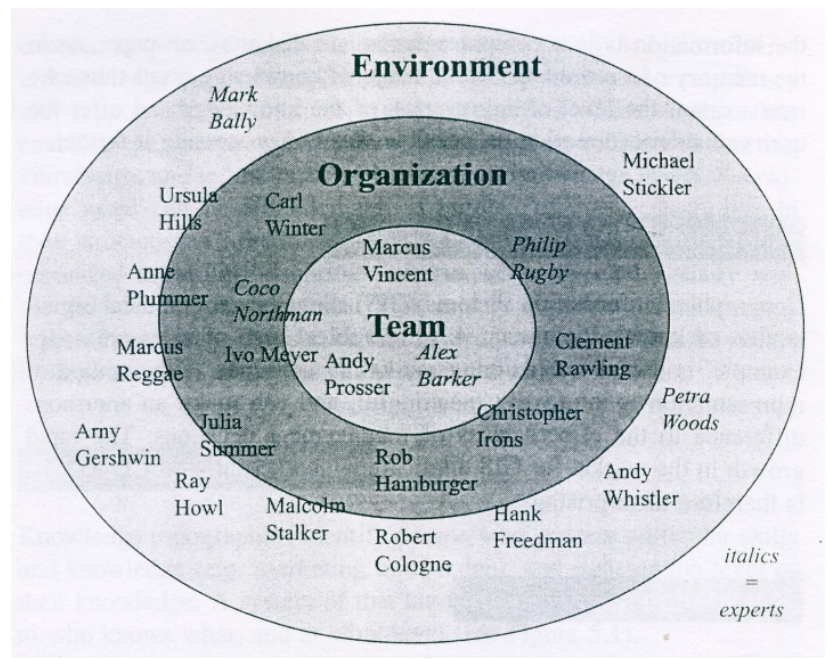

Gambar 2. Contoh knowledge source map.

\section{Product Development Matrix}

Konsep knowledge map juga bisa digunakan untuk mengatur pembagian area penelitian, sehingga antar cabang yang banyak tersebut tidak melakukan riset yang sama. Pada Contoh product development matrix di bawah ini (Gambar 3) terlihat pengaturan yang berbeda-beda dari riset yang ada yang akan digunakan oleh organisasi secara keseluruhan. Pemilihan untuk pembagian area perlu juga melihat kompetensi lokal yang dimiliki.

\section{Advisory Relationships}

Contoh advisory relationship dalam organisasi di bawah ini (Gambar 4) lebih ke memetakan sumber atau kepada siapa karyawan biasanya bertanya atau meminta pendapat kalau mendapatkan kesulitan. Ini sering digunakan sebagai langkah awal untuk karyawan dimana mereka bisa menceritakan sumber-sumber yang digunakan dalam pekerjaan sehari-hari. Pola diatas juga bisa menjadi gambaran tentang karyawan-karyawan potensial yang memang memiliki knowledge yang secara nyata menjadi leader bagi karyawan lainnya.

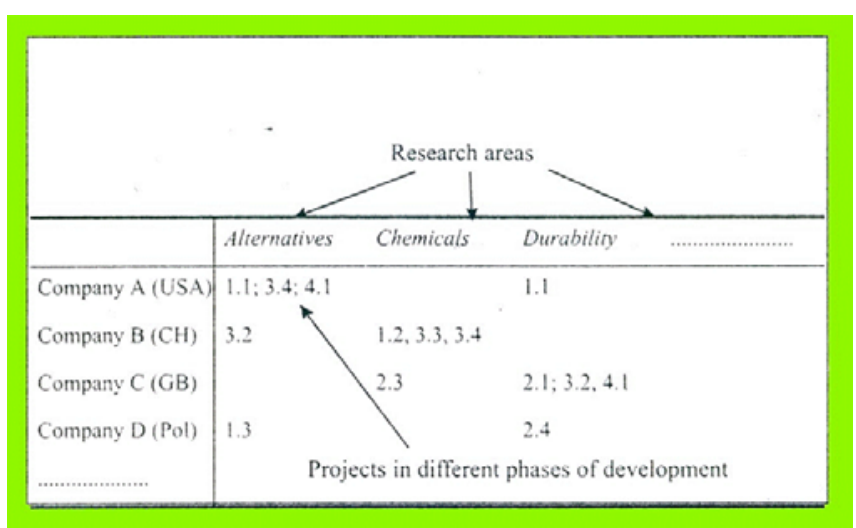

Gambar 3. Contoh product development matrix.

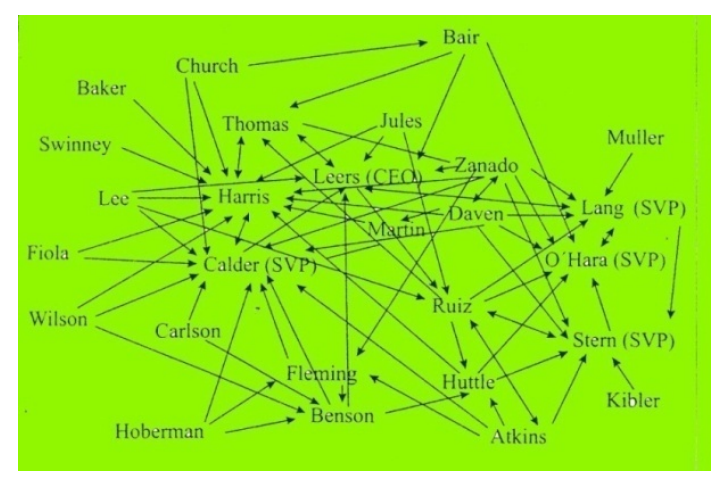

Gambar 4. Contoh advisory relationship dalam organisasi. 


\section{Membangun Pemetaan Pengetahuan (Knowledge Map)}

Beberapa prinsip dasar yang perlu dilakukan dalam membangun dan menjaga kualitas dari knowledge map antara lain: (1) identifikasi proses yang secara intensif menggunakan knowledge. Dalam identifikasi perlu fokus untuk proses-proses yang memang memiliki kualitas atau konten knowledge yang dalam. Kita tidak memetakan pengetahuan yang terlalu umum atau yang memang jarang ditanyakan atau jarang bermasalah. Tidak juga fokus ke bidang yang memiliki terlalu banyak expert sehingga tidak menyulitkan untuk bertanya. Fokusnya harus ke area yang memang sangat membutuhkan knowledge secara intensif; (2) temukan aset knowledge yang relevan dan karyawan yang ahli di bidangnya. Usahakan untuk mengalokasikan atau memetakan antara knowledge yang ada dengan para expert tersebut sesuai dengan bidang dan pemetaan pekerjaan di organisasinya.

Hal ini juga untuk memastikan kalau yang bersangkutan memang dalam keseharian terlibat dalam aspek yang sama. Misalnya, kita tidak boleh memetakan seorang mekanik sebagai ahli di accounting walaupun mungkin dulunya dia mengambil kuliah jurusan itu. Mengapa? karena akan berbahaya jika dalam pekerjaan kita tidak lagi menggunakan dan memahami prinsip accounting; (3) Indeks dengan jelas aset dan karyawannya. Pengaturan dalam sistem perlu menerapkan sistem index baik untuk aset (knowledgenya) maupun para pemiliknya (expert) untuk memudahkan mencari baik orang per orang maupun untuk orang yang mengerti di bidang tertentu di mana karyawan kesulitan menanganinya; (4) integrasikan aset yang telah diindeks dalam satu sistem navigasi yang terkait dengan proses. Lebih baik dibuatkan sistem navigasi yang mudah untuk indeks yang sudah dibuat sebelumnya dan kalau memungkinkan juga yang terintegrasi dengan setiap proses yang ada di perusahaan. Maksud integrasi di sini adalah disiapkan link di setiap area atau aplikasi di mana karyawan bekerja, sehingga kalau kesulitan bisa langsung terhubung dengan expert di organisasi yang memang bisa membantu; (5) atur mekanisme yang memungkinkan update data secara desentralisasi. knowledge map ini diatur di dalam data untuk bisa terus terupdate secara desentralisasi sehingga tidak tergantung oleh pusat. Update dengan mudah dilakukan misalnya oleh karyawan yang bersangkutan dan approval dari atasannya atau dengan admin yang melakukan klarifikasi terhadap isiannya. Ini untuk meningkatkan dan memperkaya isi dari knowledge map dengan semakin banyaknya acuan dan tidak hanya tergantung ke orang-orang tertentu saja.

\section{Membangun Transparansi dengan Segala Tuntutannya}

Dalam membangun transparansi knowledge ini tentu saja dibutuhkan cukup banyak pengorbanan baik untuk menganalisis para expert yang ada (misalnya akan dibuatkan knowledge map) maupun dalam menginventarisasi dan menuangkan knowledge dari expert (kalau yang dibangun adalah knowledge repository-nya). Dibutuhkan biaya dan waktu untuk mengukur dan merekam skill yang ada, seperti untuk melakukan wawancara, penyebaran kuesioner, pengembangan prosedur tes. Dibutuhkan juga fokus untuk meningkatkan transparansi ke area skill yang memang kritis dan penting bagi organisasi, yang seringnya justru tidak dipahami oleh organisasi, sehingga sering kali pembangunan dilakukan di area yang justru tidak terlalu strategis. Perhatikan aspek yang menyentuh kehidupan pribadi, harus tetap mengutamakan faktor pribadi dari setiap orang. Expose atau memperkenalkan para expert kita terkadang juga tidak selalu menjadi hal yang baik, karena cukup rawan dengan pembajakan (karena secara langsung memperkenalkan secara luas sebagai expert) atau malahan kontribusinya secara strategis akan berkurang karena lebih banyak fokus pada menularkan atau menyelesaikan masalah yang terkadang terlalu sepele.

Transparansi terkadang juga bisa merusak, khususnya kalau tidak adanya perhatian terhadap kehidupan pribadi. Atau kalau kita tidak bisa menjaga knowledge yang sudah dikelola dengan baik, bisa memungkinkan ada karyawan yang mengambil dan menjual kepada kompetitor khususnya untuk karyawan yang dibajak untuk pindah. Sebenarnya musuh utama dari tranparansi knowledge yaitu karyawan-karyawan yang sudah punya reputasi baik dan terkenal dengan knowledgenya. Mereka 
biasanya tidak tertarik dengan usulan atau cara sederhana tetapi secara luas mengeluarkan knowledge yang dimilikinya.

\section{Membuat Knowledge Kolektif Menjadi Nyata}

Faktor ideal dalam identifikasi juga perlu dalam menyatukan pengetahuan kolektif yaitu pengetahuan team (kelompok). Seringkali dalam mengerjakan sesuatu pekerjaan dibentuk team yang saling melengkapi. Pengetahuan detail non individu dalam pekerjaan tertentu juga perlu dilihat; analisis harus bisa menyatukan pengetahuan tersebut sebagai suatu kesatuan yang utuh.

Beberapa keunggulan dalam sudut pandang analisis kolektif knowledge antara lain: (1) pemetaan proses utama (core process) akan bisa melihat proses inti yang dikerjakan setiap orang, dan bisa melihat secara utuh aliran informasi dan proses dalam proses kerja. Akan lebih terlihat jelas peran setiap orang baik yang inti maupun yang kurang penting; (2) adanya akses ke data/pengalaman masa lalu dari proyek sebelumnya. Pemetaan dari kolektif knowledge seringnya terbentuk dari pengalaman atau proyek yang dikerjakan di masa lalu. Pendekatan ini biasanya juga digunakan untuk menangkap pengalaman yang ada dari proyek-proyek yang ada di masa lalu. Banyak pengalaman dan knowledge yang bisa diambil dari proyek sebelumnya mulai dari penyusunan proposal, pengaturan anggaran, pengaturan team kerja yang ideal sesuai keahliannya sampai pada pengalaman dari masalah dan solusi.

\section{Mensejajarkan Tren dalam Lingkungan Knowledge}

Proses identifikasi sebenarnya juga perlu melihat tren dan perkembangan knowledge di lingkungan sekitar; tidak hanya apa yang sudah ada di organisasi. Diperlukan sedikit perhatian pada tren yang dimaksud dan sumber pengetahuan lingkungan dalam proses identifikasi, yaitu: (1) bagaimana mengatasi atau strategi terhadap banyaknya informasi eksternal yang beredar; termasuk bagaimana mengumpulkan, merangkum, dan mengintisari yang sesuai untuk perusahaan; (2) peran teknologi juga bisa dimanfaatkan oleh perushaaan sebagai alternatif khususnya dalam mendapatkan partner atau rekan kerja. Informasi dan knowledge dari perkembangan teknologi membuka banyak jalan buat perusahaan; (3) berusaha mendengarkan masukkan yang ada buat perusahaan dari semua pihak yang terkait; (4) menganalisis sumber-sumber informasi penting dan tetap memantau perkembangan di pusat-pusat informasi tersebut; (5) melihat transparansi dari knowledge dan informasi yang sudah dibangun dan disediakan oleh partner eksternal atau rekanan eksternal sehingga tidak terjadi pengumpulan informasi yang sama; (6) konsultan kadang diperlukan juga melihat spesialisasi konsultan yang membantu apakah memiliki keahlian di bidang yang sesuai dengan perusahaan.

\section{Pertimbangan Identifikasi Dalam Pendekatan Pembangunan KM}

Dalam proses identifikasi knowledge, di samping fokus ke faktor knowledge yang ada, perlu juga melihat beberapa faktor pertimbangan, khususnya pendekatan dalam pembangunan KM.

Pertama adalah pemanfaatan internet and intranet. KM lebih baik dibangun di dalam platform yang berbasis web untuk menjamin kemudahan akses untuk platform yang berbeda di antara banyak sistem di organisasi. Hal ini juga merupakan sesuatu yang paling populer dan mudah untuk digunakan oleh semua lapisan karyawan. Perlu juga memikirkan apakah KM yang dibangun terbatas di internal saja (intranet) atau juga bisa diakses dari luar (internet). Pertimbangan utama adalah dari cakupan area perusahaan. Bisa dimulai dengan intranet. Ketika sistem akan digunakan lebih luas, bisa langsung dipublikasi. Ini juga yang menjadi alasan lain memilih platform web dibandingkan berbasis desktop.

Kedua, penggunaan intelligent agents. Perlu pertimbangan juga apakah perlu menggunakan intelligent agent secara khusus untuk membantu perusahaan dalam membangun KM ini. Kalau hanya 
mengandalkan resoure internal apakah bisa mendapatkan cukup respek dan waktu dalam pembangunan. Figur khusus - disamping lebih dihargai - biasanya akan bisa melihat lebih jernih knowledge yang ada, karena karyawan umumnya terbiasa dengan pekerjaan dan tidak lagi melihat aspek khusus dalam sesuatu yang dikerjakannya. Ketiga, perhatian akan gap (perbedaan) knowledge yang ada. Diperlukan analisis gap dalam penggunaan knowledge yang ada pada karyawan. Jadi analisis juga mencakup tingkat pemanfaatan dan tingkat awareness karyawan dengan teknologi yang akan digunakan. Pertimbangan ini juga mempengaruhi konsep rancangan terhadap sistem yang akan dibuat nantinya.

Keempat, "mengadopsi atau membangun ulang?”. Perlu melihat lebih rinci juga tentang knowledge yang kita miliki apakah masih bisa termasuk general sehingga bisa menggunakan sistem KM yang sudah banyak beredar (hanya perlu melakukan sedikit perubahan saja), atau memang cukup unik sehingga harus membangun sendiri. Expert internal yang dimiliki dalam proses pembangunan KM juga menjadi faktor yang mempengaruhi apakah lebih baik dibangun sendiri atau lebih baik dari ekternal dengan membangun sepenuhnya atau menggunakan aplikasi KM yang sudah tersedia. Kelima, kesadaran akan pentingnya KM. Perlu memastikan apakah di organisasi sudah memiliki kesadaran dan tingkat pemahaman yang baik tentang organisasi yang berbasis knowledge, agar tidak menjadi sia-sia untuk semua aplikasi dan investasi pembangunan KM yang sudah dilakukan.

\section{PENUTUP}

Dari paparan di atas, terurai pendekatan yang ideal untuk melakukan identifikasi knowledge. Dalam proses nyatanya, perlu memperhatikan banyak hal dan menggunakan beberapa pendekatan yang tepat dengan perusahaan masing-masing. Pendekatan analisis perusahaan secara structural, functional dan behavioral lebih mudah dan cocok untuk digunakan dalam identifikasi knowledge perusahaan.

\section{DAFTAR PUSTAKA}

Probst, G., Raub, S., Romhardt, K. (2000). Managing Knowledge: Building Blocks for Success. London: John Wiley and Sons.

Tobing, Paul L. (2007). Knowledge Management: Konsep, Arsitektur dan Implementasi. Yogyakarta: Graha Ilmu.

Widayana, Lendy. (2005). Knowledge Management: Meningkatkan Daya Saing Bisnis. Malang: Bayumedia Publishing. 